\title{
Changes in the composition and content of polyphenols in chocolate resulting from pre-treatment method of cocoa beans and technological process
}

\author{
Bogumiła Urbańska' ${ }^{1}$ - Dorota Derewiaka ${ }^{1} \cdot$ Andrzej Lenart $^{2} \cdot$ Jolanta Kowalska $^{1}$
}

Received: 11 March 2019 / Revised: 5 July 2019 / Accepted: 13 July 2019 / Published online: 31 July 2019

(c) The Author(s) 2019

\begin{abstract}
Chocolate is one of the most desired confectionery products in the world. Its production technology includes a series of processes conducted in appropriate conditions of the temperature and time. Most of these operations contribute to the degradation of valuable, natural and desired bioactive compounds; hence, producers search for novel technologies and solutions that would enable minimizing these losses. In 2012, the EFSA confirmed advantages of components within cocoa powder to health. This review is focused on analyzing the effect of particular stages of the production process, with consideration given over to the kind of raw ingredients of the finished product on the bioactive compound's make-up in the products made in cocoa beans products subjected to the "traditional" process using both high and low temperatures. Due to the high temperature used during roasting, it is witch is one of the main processes affecting both the quality and sensory properties of the cocoa beans and products made from them. Each variety differs in size and beans color, resistance to the climatic resistance, and beans composition. Collected data allow us to establish which stages and which processes require further studies and analyses to be most useful for chocolate manufacturers not only in terms of the manufacturing repeatability of products, but also in developing an assortment of products having a positive effect on human health and well-being.
\end{abstract}

Keywords Cocoa $\cdot$ Chocolate $\cdot$ Polyphenols $\cdot$ Bioactive compounds $\cdot$ Health effects $\cdot$ Antioxidants

\section{Introduction}

Ample research studies conducted have over the recent past addressed the impact of natural antioxidants on human health. In response to scientific findings and consumer expectations, food manufacturers extend their market assortment with products rich in biocomponents.

Bioactive compounds inter alia among the anti-nutrients (polyphenols or caffeine) occurring naturally in the raw material or synthesized in the course of the technological process (Maillard reaction products), which may either

Bogumiła Urbańska

bogumila_urbanska@sggw.pl

1 Department of Biotechnology, Microbiology and Food Evaluation, Faculty of Food Sciences, Warsaw University of Life Sciences, 159 Nowoursynowska str., 02-787 Warsaw, Poland

2 Department of Food Engineering and Process Management, Faculty of Food Sciences, Warsaw University of Life Sciences, 159 Nowoursynowska str., 02-787 Warsaw, Poland reinforce, debilitate or modify physiological and metabolic functions of the body [1]. They exhibit various positive effects like antioxidative activity, enzyme inhibition or induction, induction of receptors activity, as well as induction and inhibition of gene expression [2]. The dominant antioxidant compounds in cocoa beans and their processing products are polyphenols which is confirmed by numerous publications. Therefore, numerous studies have undertaken the analysis of these groups of compounds due to the fact that they undergo the largest changes in the technological process, and also confirmed their favorable effects on the human body. In 2012, the EFSA confirmed the beneficial effect of polyphenols (flavanols in particular) contained in cocoa powder on the cardiovascular system of man [3]. The market of chocolate products is developing dynamically and the offered assortment includes both high-cocoa chocolate (with the addition of cocoa powder) and chocolate not subjected to high-temperature treatment (raw). Chocolate is one of the most desired confectionery products [4]. Its production technology includes a series of processes conducted in appropriate conditions of temperature and time. 
High temperature used during cocoa beans processing has a destructive effect on polyphenols which are desirable constituents of the finished product. Hence, supported by results of multiple research studies, producers modify both the technological process and the composition of raw materials, so that their products had not only attractive sensory values but also-first and foremost-a positive impact on human health. The offered assortment includes, among others, highcocoa chocolate containing from $70 \%$ to even $99 \%$ of cocoa ingredients, which affects their health-promoting functions, as well as "raw" chocolate subjected to a low-temperature treatment which has a protective effect on their labile components, including, e.g., polyphenols.

Chocolate contains both nutrients like proteins, fat and carbohydrates and bioactive ingredients. These compounds may exert both positive or negative effects in vivo. Bioactive compounds includes polyphenols, tocopherols, mineral compounds, sterols or purine alkaloids fatty acids. Despite the high energy value resulting from the sugar and fat content, chocolate has a low glycemic index from about 14 to about 53 depending on the type of product. Many studies have confirmed that systematic consumption of a piece of dark chocolate $(10 \mathrm{~g})$ is beneficial to the cardiovascular system and is therefore recommended as a component of everyday diet $[5,6]$.

The bioactive content of found in cocoa beans and products made from them is determined by multi-oriented and complicated transformations of various characters that develop at each stage of the technological process. Most of these operations contribute to degradation of valuable, natural and desired bioactive compounds, and so producers search for novel technologies and solutions that would enable minimizing these losses. One of these includes manufacturing products from non-roasted cocoa beans subjected only to low-temperature treatment. It is, therefore, advisable to analyze the effect of particular stages of the production process, with consideration given to raw material types and properties of the end product, on the make-up of bioactive compounds in products made from cocoa beans subjected to traditional and lower-temperature treatments.

\section{Bioactive compounds of cocoa beans}

The bioactive effect of cocoa beans and their processing products results mainly from the presence of polyphenols in their composition. Although the beans also contain other ingredients, such as methylxanthine (mainly caffeine and theobromine), their content is much lower. Moreover, greater antioxidant and pro-health effect is attributed to polyphenols, and their qualitative and quantitative composition changes significantly under the influence of high temperature, $\mathrm{pH}$, or access to oxygen.
Polyphenols, being secondary metabolites, are one of the most plentiful and widespread groups of naturally occurring substances in the plant kingdom. They are synthesized biogenetically in two major primary pathways of synthesis: shikimate pathway and acetate pathway [7]. Cocoa beans are rich in polyphenols (ca. 15\% of beans dry matter), as are wine, vegetables or tea [8]. Three groups of polyphenols may be identified in cocoa beans: proanthocyanins (ca. $58 \%$ ), catechins or flavan-3-ols (ca. 37\%) and anthocyanins (ca. 4\%) $[9,10]$. The major and predominating catechin of cocoa beans is (-)-epicatechin which represents ca. $35 \%$ of total Catechin is a component of cocoa tannins which are responsible for color changes and for astringent after-taste of beans and products made of them. Bitterness of epicatechins is undesirable; hence, producers try to reduce the amount of this flavonoid in the finished product [11]. Procyanidins of cocoa are shown by: dimers, trimers or flavan-3,4-diol oligomers $[12,13]$. Other polyphenols include: flavones (kaempferol, apigenin, luteolin, and glycosides) and phenolic acids (chlorogenic, caffeic, syringic acid, coumaric and ferulic). The make-up of polyphenols very strongly depends on: origin, genotype, beans processing and ripeness degree $[14,15]$.

Methylxanthines, like theobromine $\left(\mathrm{C}_{7} \mathrm{H}_{8} \mathrm{~N}_{4} \mathrm{O}_{2}\right.$, 3,7-dimethylxanthine or 3,7-dihydro-3,7-dimethyl-1H-purine-2,6-dione) and caffeine $\left(\mathrm{C}_{8} \mathrm{H}_{10} \mathrm{~N}_{4} \mathrm{O}_{2}, 1,3,7\right.$-trimethylpurine-2,6-dione), represent another group of bioactive compounds of cocoa beans [16]. The content of methylxanthines and the theobromine: caffeine ratio varies depending on cocoa genotype. Non-fermented cocoa from West Africa (Forastero) contains ca. $4 \%$ of theobromine and $0.2 \%$ of caffeine (in fat-free dry material). American fine-grained cocoa beans are richer in caffeine $(0.30-0.60 \%)$; whereas, the content of their theobromine ranges from ca. $2.8 \%$ to ca. $3.5 \%$ in non-fat cocoa solids [17].

Due to the fact that polyphenols are the dominant group of bioactive compounds in cocoa beans and their processing products and undergo significant qualitative and quantitative changes in the technological cycle, this article focuses mainly on the changes in polyphenols content as indicators of not only the course of processes but also the level of antioxidant activity.

\section{Effect on health}

Apart from economic importance, intake of cocoa products has positive for health $[9,18,19]$. Polyphenolic compounds of cocoa beans exhibit anticarcinogenic [20-22], anti-atherosclerotic [23], anti-inflammatory and skin-protective (antiaging) properties, which is associated with their antioxidative potential $[24,25]$. 
The first clinical survey addressing the effect of consuming fat-free components of cocoa beans on a human body was carried out in 1996 and demonstrated that the consumption of $35 \mathrm{~g}$ of fat freecocoa suppressed LDL oxidation between the 2 nd and 4th hour after consumption. Many new investigations have been conducted ever since with different forms of cocoa which have demonstrated its health-promoting effects that may be summarized in three main categories: antioxidative properties, protection of the cardiovascular system, and anticarcinogenic properties [26-29].

Although published scientific findings suggest that chocolate consumption may have a beneficial effect on health, it needs to be noticed that chocolate is high in sugar and fatsugar. Therefore, its high consumption can contribute to body mass gain. For this reason, its intake should be thought of in the context of a healthy diet, i.e., in moderate amounts only (20-25 g a day) [30, 31].

Achieving a balance between taste and health outcomes remains a challenge, as the impact of the process on both the content of bioactive ingredients and the properties preferred by consumers (taste, smell) must be taken into account. It was recommended that the "omics" technologies (proteomics, transcriptomics, glycomics and metabolomics) may be employed to monitor cocoa beans processing into products with high contents of bioactive compounds and desired taste [15]. It was proved that the antioxidative capabilities of cocoa and chocolate products were correlated with post-prandial blood concentrations of proanthocyanidins and epicatechins [32]. The ability to scavenge oxygen radicals, i.e., the total antioxidative potential, increases significantly as soon as $1 \mathrm{~h}$ after consumption of dark chocolate and maintains high for ca. $4 \mathrm{~h}$. Such an effect is not induced by milk chocolate, which may be linked with lower absorption of epicatechin from the gastrointestinal tract caused by the addition of milk proteins to chocolate of this type [32].

Cocoa beans may also display a stimulating effect because of the presence of caffeine and theobromine [33]. Nehlig [34] suggested that in human brain, alkaloids compete with adenosine, block its receptor and by this means evoke excitation. In turn, caffeine is claimed to be a catalyst of the release of epinefrin and other catecholamines from adrenal glands, thus inducing reactions stimulated by them. Methylxanthines were proved to exhibit health-promoting properties in diseases associated with cell damage in the nervous system [34]. While caffeine effectively stimulates effect brain by increasing blood pressure and enhancing psychomotoric reactions, diuretic agent, theobromine acts as a muscle relaxant, and blood pressure reducer [16, 18].

\section{Various effects on the quality of cocoa beans}

\section{Genotype}

Cocoa tree (Theobroma cacao) and its fruits (beans) are characterized by a significant genetic diversity, which determines properties of products made of them. Known are over 14,000 cultivars of cocoa tree [35], with the most common ones being: Forastero, Criollo and Trinitario cultivars [20, 36-40].

Each cultivar differs in the size and color of beans, resistance to climatic conditions, and beans composition. As reported by Trognitz et al. [41], the Forastero type has pods with thicker skin, beans with bitter taste and strong aroma, is easy to cultivate and high-yielding. Cocoa made of its beans has a dark color, perceptible intensive aroma, as well as bitter and astringent taste. Today, Forastero and its various strains are the most commonly grown and processed cocoa beans varieties. They are cultivated mainly in Western Africa and their production constitutes ca. 95\% of the global production [42].

Criollo cocoa is less bitter owing to a low content of theobromine, has a low $\mathrm{pH}$ value which negatively affects its flavor profile [43], and also has a high content of pyrazines being one of the major compounds determined during roasting [44]. In turn, according to Giacometti et al. [15], cocoa beans of Criollo cv. have high contents of procyanidins, aroma precursors, reducing sugars, and amino acids. In turn, the Trinitario type originates from Trinidad and encompasses all products of natural hybridization and recombination of the Criollo and Forastero plantations [39]. Its beans have various colors, though are rarely white; while, trees are susceptible to pest infestation and infections with diseases intermediate for the population [42]. Polyphenols are formed, among other things, in response to plant stress. Changing environmental conditions, too much sunshine, the use of plant protection agents and the action of pests have an impact on the reactions of cocoa trees and thus on the polyphenols content of the beans. Cocoa trees are, therefore, most often grown in the shade of other trees, such as bananas, to provide protection from the sun. An important factor is the control of the plant protection agents used, which is not an easy task due to the fragmentation of the plantations.

According to Peláez et al. [45], chocolate made of Forastero cocoa beans shows basic taste. In the study conducted by Oracz et al. [46], cocoa beans of Forastero cv. from Brazil had the highest contents of flavan-3-ols, anthocyanins and flavonols, whereas samples of Trinitario cv. from Papua New Guinea had the lowest content of polyphenols.

It should be noted that sensory properties, such as the taste, color and aroma of cocoa beans are due to, among others, from the content and composition of polyphenols contained in them. All the more, it is necessary to analyze the changes in the content of phenolic compounds from the point of view of both health and consumer acceptance resulting largely from the sensory characteristics of the product. 


\section{Geographic location}

The chemical composition of cocoa beans and products made of them varies and depends on beans type, geographical location of plantations, beans maturity as well as on methods used for bean processing, fermentation and drying [47].

The main objective of a research carried out by Bruna et al. [48] was to determine contents of bioactive compounds (polyphenols, hydrocolloids) in husk of cocoa beans of various geographical origin, i.e., Ghana, Madagascar, Ecuador, Trinidad and Venezuela. The antioxidative effect measured with an electron spin resonance (ESR) was highly correlated with the content of polyphenols. Analyses demonstrated significant differences in contents of the studied compounds dependant on where grown. Husks of cocoa beans from Madagascar were characterized by a higher content of polyphenolic compounds and water-soluble pectins when compared to all other analyzed samples. In contrast, the cocoa hulls from Ecuador contained the lowest values of polyphenols as well as of antioxidant activity.

Beside genotype variations, fermentation and ripeness of the cocoa beans, soil and climate conditions as well as stress are significant factors influencing the content of the bioactive compounds.

The effect of the geographical origin of cocoa beans was confirmed by Macedo et al. [49], who demonstrated the activity of cocoa enzymes to depend on beans genotype and geographical origin and on the applied parameters of the fermentation process.

A study conducted by Carrillo et al. [50] on the effect of geographical origin on contents of polyphenols and methylxanthine and on the antioxidative level of cocoa beans from different regions of Columbia demonstrated significant $(p<0.05)$ differences in the content of total polyphenols (TPC) and contents of flavan-3-ols, catechin epicatechin, theobromine and caffeine and antioxidative capability. Findings would suggest that the lower the altitude, the higher the contents of polyphenols, epicatechin and flavan-3-ols in the cocoa tree fruits. The results of the main ingredients analysis (PCA) indicate that the theobromine/caffeine ratio can be used as a parameter to classify cocoa beans according to their origin.

\section{Changes in contents of polyphenols during processing}

Apart from soil and environmental conditions, region of cultivation properties of products made of cocoa beans is affected by parameters of processing the beans are subjected to.

\section{Fermentation}

The preliminary and key process which determines the qualitative and physicochemical traits of cocoa products is fermentation. It is carried out on plantations, usually under natural environmental conditions.

To ensure better control of the fermentation process and overall product quality, it is suggested to replace traditional process of natural fermentation of cocoa beans with starter cultures. Promising attempts of reaching this goal have been undertaken and described in scientific literature [51-53].

As shown by Giacometii et al. [15], yeast, lactic acid bacteria and acetic acid bacteria had protective effects on the levels of polyphenols, whereas aerobic spores and moulds exerted negative effects. Longer fermentation causes a greater decrease in the content of flavanols [35]. Trognitz et al. [41] reported that polyphenols content decrease during fermentation could be ascribed to special genetic and anatomic traits of beans.

During fermentation, the precursors of the flavor of chocolate are run by the endogenous enzymes of cocoa beans. The fermentation process results mainly in $\mathrm{pH}$ decrease, which enhances enzymatic activity. During the fermentation process, the cocoa beans pulp coating is degraded by microorganisms (yeast, acetic acid bacteria and lactic acid bacteria) which are naturally found in the environment, and temperature increases to ca. $50{ }^{\circ} \mathrm{C}$ [54]. Macedo et al. [49] designed a study to explain the activity of polyphenolic oxidase in the pulp and beans of two cocoa types. Results of this study demonstrated specificity and differences between the two analyzed varieties as well as between the pulp and beans of each type. These authors suggested that special grades should be adopted for each varieties based on optimal parameters to extend the period of the maximum activity of polyphenolic oxidase during the fermentation process, which would contribute to improving of cocoa beans quality and, consequently, of chocolate quality [49].

During fermentation, the level of polyphenols decreased by ca. $70 \%$, whereas that of (-)-epicatechin (the major substrate of polyphenoloxidase) by even ca. $90 \%$ of the initial content [55].

Anthocyanins are usually rapidly degraded in the fermentation process (93\% loss after 4 days), which was considered an indicator of cocoa beans fermentation degree $[55,56]$. The optimal duration of the fermentation process was determined as 6 days [15].

Differences between results obtained by various scientists, who conducted experiments under different conditions and with different materials, confirm the complexity of processing treatments of cocoa beans as well as diversity of the raw material. The main reason behind these losses is the escape of some amounts of cocoa beans components with fluid leakage. Chemical analyses of samples in Afoakwa 
et al. [56] study showed lower contents of ash (minerals), protein and fat in fermented beans.

Elwers et al. [57] saw a greater decrease in catechin content during fermentation and drying of Criollo beans samples compared to the samples from the other analyzed genotypic groups. This could be responsible for the mild taste of chocolate made of beans of this type.

\section{Drying}

During drying, the content of polyphenols decreases significantly as an effect of high temperature, diffusion of components from beans with evaporating water, and enzymatic browning processes [21].

The stage of drying plays a major role in reducing astringency bitterness, and acidity also in the development of the characteristic taste and brown coloring [13, 17]. The oxidation process initiated during fermentation is continued at the stage of drying. Still active polyphenolic oxidases catalyze polyphenols transformation into quinones, that are subjected to further condensation with free amine and sulfhydryl groups, which leads to the synthesis of brown polymers [58]. Even though drying appliances are increasingly more popular, natural sun-drying is still often in use $[39,59]$. Many investigations conducted to compare natural and artificial methods for beans drying indicate that natural sun-drying yields far better effects [17, 60, 61], and that drying in special appliances may lead to the formation of non-specific and undesirable aromas like rubbery or gasoline-like [62]. The profile analysis of water content changes at various temperatures and drying time optimization may be accomplished using models developed by, e.g., GarciaAlamilla et al. [63] or Hii et al. [64-66]. By this means, quality parameters of dry cocoa beans may be standardized, while batches of cocoa beans supplied to chocolate producers may be more uniform.

In the study conducted by de Brito et al. [67], the content of phenolic compounds decreased by $32 \%$ in the dried sample, compared to the fermented sample. It is a common practice that chocolate producers merge few batches of cocoa beans to achieve a uniform and stable mixture and to become independent of the country of origin or supplier of cocoa beans. Processing parameters can be standardized after mixing to obtain the expected characteristics of the cocoa beans mixture $[68,69]$. In this case, studies should be undertaken to unify agricultural practices accordingly to quality requirements set by chocolate producers, so that they could be considered in operational decisions made in the technological process [40].

The bitter taste of cocoa results mainly from contents of theobromine, caffeine and phenolic compounds in cocoa beans $[69,70]$. Even though alkaloids do not undergo chemical transformations during fermentation and drying, ca. $30 \%$ of these compounds are lost by diffusion and migration inside beans [71]. A research conducted by Peláez et al. [46] showed contents of theobromine and caffeine to decrease by ca. $21 \%$ and $60 \%$, respectively, during fermentation and drying of cocoa beans.

\section{Roasting}

Due to high temperature used during roasting, it is one of the most important principle processes affecting the quality and sensory properties of cocoa beans and products made of them. Generally, taste is claimed to be positively correlated with a high roasting degree only till the excess roasting point [40]. Roasting is usually conducted for 5-120 min (usually from 10 to $35 \mathrm{~min}$ ) at temperatures from 110 to $160^{\circ} \mathrm{C}[14$, $21,72]$.

It radically affects the content and make-up of polyphenols [14]. Polyphenols are thermolabile molecular structures, and their content decreases upon high temperatures and prolonged time of the roasting process. High temperatures can induce epimerization of (-)-epicatechin to (-)-catechin and of $(+)$-catechin to (+)-epicatechin [73]. The ratio of epicatechin to catechin, which was suggested as an indicator of cocoa processing, decreases during roasting. This caused more rapid degradation of (-)-epicatechin than of catechin [21]. Procyanidins also undergo epimerization; however, in their case, these are more complex processes because procyanidin molecules are dimers or polymers [14]. The content of high molecular weight procyanidins decreases at the beginning of the process and then increases. The likely reason of this phenomenon may be the polymerization of low-molecular-weight compounds. Low-temperature and short roasting is believed to better preserve polyphenolics content [21]. Temperatures below $140{ }^{\circ} \mathrm{C}$ are normally recommended.

Stanley et al. [74] investigated the impact of whole-bean roasting on the polyphenol content, aroma-related chemistry and in vitro pancreatic lipase inhibitory activity of cocoa under a range of roasting conditions. It turned that total phenolics, (-)-epicatechin, and proanthocyanidin (PAC) dimer-pentamer content was reduced by roasting, but roasting at $150{ }^{\circ} \mathrm{C}$ or more increased the levels of hexamers of catechin and proanthocyanidin.

The roasting effect on the antioxidative properties of cocoa beans depends on the comparative amounts of thermal degradation of naturally occurring phenolic compounds and the introduction of new antioxidants like Maillard reaction products and polymeric pigments. Oracz and Nebesny [75] demonstrated that low-temperature heat treatment with moist air may be used to increase contents of phenols and antioxidative activity of roasted cocoa beans. Study results prove cocoa beans to be a positive source of antioxidants after roasting. 
Today, many studies [76-78] are in progress with the aim to, e.g., develop technology for cocoa beans and cocoa cake roasting (temperature, time, humidity, fineness of the beans flow rate of air or flow rate of air) that would allow manufacturing a semi-product (cake, pulp) to be used for manufacturing chocolate products with as much as possible increased content of bioactive compounds.

In the roasting process, there is a significant reduction in polyphenol content, as well as a change in their composition. However, it should be remembered that the roasting process is aimed at loosening the beans structure, which facilitates the removal of the husk, and in the further stages of pressing the fat. In addition, due to the high temperature, the content of (-)-epicatechin corresponding to astringent and undesirable taste also decreases. Some acids (e.g., acetic acid) are also removed, which reduces the acidity of the intermediate, expected from the point of view of qualitative features. One of the methods of improving the bioactive value of chocolate and other cocoa bean products is the use of low roasting temperatures and other stages, which was applied in the production of chocolate called "raw".

\section{Alkalization}

Cocoa beans, pulp or cocoa powder shall be alkalized by treatment with acidic sodium or potassium carbonates [69]. Many studies have indicated that increasing $\mathrm{pH}$ value from 5.7 to 7.5 has a negative effect on taste acceptability [79, 80]. This may cause extraction of elements and their elution, which in turn may contribute to lower contents of mineral components in the finished product.

A research conducted by Miller et al. [81] demonstrated that $\mathrm{pH}$ change caused by the addition of alkaline agents influenced the total polyphenols content in the produced cocoa powder. It has turned out that natural cocoa powders ( $\mathrm{pH}$ 5.39-5.76) showed higher levels of antioxidative capability and total content of polyphenols. Alkalization causes high losses of polyphenols (over $60 \%$ loss of total polyphenols content) and changes their composition. The greatest losses are observed for epicatechin and catechin (up to ca. $98 \%$ and $80 \%$, respectively) as well as for quercetin (ca. 80\%) [15]. Further degrees of alkalization lead to a noticeable decrease in polyphenol content [82]. These changes may be ascribed to oxidation and polymerization of polyphenols under alkaline conditions [15]. The process of alkalization has a negative impact on the content of methylxanthines, the content of which decreases along with an increasing degree of alkalization, and the greatest losses were observed for theobromine (over 20\%) [83].

In the study conducted by Stanley [84], treatment of cocoa powder with $\mathrm{NaOH}$ increased catechin content by $40 \%$, but reduced epicatechin and proanthocyanidins by
23-66\%. In their work, they showed the first application of proanthocyanidins and preliminary prognostic model of the effect of alkaline treatment on cocoa polyphenols.

The use of alkalization is discussed among scientists and entrepreneurs. Increasing the $\mathrm{pH}$, more distinct colour, better solubility of cocoa powder are the arguments that lead to the use of alkalization. However, the very action of chemical compounds, especially from the health point of view, as well as studies confirming a significant reduction in the content of bioactive compounds led the manufacturers of "raw" chocolates to abandon the use of alkalization.

\section{Conching}

Conching is a few-day stage of heat treatment which contributes to the development of the final taste and smooth texture of chocolate $[35,85]$. It is conducted by mixing bulk at high temperatures (over $40{ }^{\circ} \mathrm{C}$ ) [30]. Dark chocolate is usually conched at $70-82{ }^{\circ} \mathrm{C}$ [16]. This process improves the taste profile and decreases contents of free fatty acids and other volatile waste products of cocoa beans $[15,36]$.The addition of selected components (saccharose and lecithin) induces the effect of dilution of polyphenols and their antioxidative properties [10].

Depending on production line and particular stages of the production process, the manufacture process of chocolate was found to cause various degradation of health-promoting compounds [86]. According to Gültekin-Ozgüven et al. [77], during conching, a reduction in phenolic content is normally expected due to high temperatures and oxygen in roasting and conching steps.

As noted by Di Mattia et al. [25], the conching process does neither impact the phenolic content and neither form, nor antioxidant activity. Only $3 \%$ the variations were found, regardless of the time/temperature combination used.

The own research including the analysis of the influence of conching in different temperature and time conditions confirmed the statistically significant influence of this process on the content of polyphenols. Unpublished results confirm the significant influence of temperature, combined with time of its action, on the content of phenolic compounds.

\section{Tempering}

Tempering is a process of stirring the cocoa mass for a few hours combined with lowering and increasing the temperature. The aim of this process is to obtain a stable form of crystalline fat $(\mathrm{V})$, so that the chocolate is stable and does not dissolve in the fingers [87]. The control of this process is important for the quality of the product, and tempered chocolate is shiny, snap even-colored and smooth tasting, while badly tempered chocolate is chewy, grainy and chalky, 
within the form of an unattractive, dull brown mass because of fat blooming. The tempering process does not apply high temperatures (max. $45^{\circ} \mathrm{C}$ ); therefore, loss of polyphenols at this stage has not been proven.

\section{Composition of bioactive compounds in different types of chocolate}

\section{Bitter and high-bitter chocolate}

The processing of cocoa beans results in significant losses of polyphenols. However, their content in the finished products (e.g., in chocolate) depends also on product formula and content of non-fat cocoa solids [88]. The content of polyphenols in dark chocolate ranges from 1.7 to $8.4 \mathrm{mg} / \mathrm{g}$ of product.

Dark chocolate is a good provider of dietary flavonoids, mainly comprised of (+)-catechin, (-)-epicatechin, and their polymeric and oligomeric procyanidins. However, antioxidant capacity and flavonoid content are affected during chocolate manufacturing [77].

Dark chocolate may contain $600 \mathrm{~g}$ of cocoa pulp $/ \mathrm{kg}$ of chocolate, and also cocoa powder-being valuable because of its polyphenols [30]. Contents of these ingredients affect the total content of flavanols in chocolate. The more cocoa powder added, the higher the content of polyphenols in chocolate. One hundred grams of dark chocolate contain ca. $100 \mathrm{mg}$ of flavanols, whereas $100 \mathrm{~g}$ of cocoa powder contains ca. $250 \mathrm{mg}$ of flavanols [89]. The content of polyphenols in chocolate is influenced not only by contents of cocoa pulp and cocoa powder, but also by cocoa beans species and parameters of its processing. Chocolate made of Forastero cocoa beans (grown mainly in Western Africa) is less bitter and sour than chocolate made from Trinitario or Criollo cocoa beans, which may result from the content of polyphenolic compounds which may give rise to a bitter taste [70].

Chocolate is produced with the use of cocoa powder which has a resulting in positive effect on human health, as confirmed by EFSA [19]. Its beneficial effect results from its polyphenolic compounds, the source of which are the nonfat cocoa solids. The higher the content of NFCS in chocolate, the higher the content of polyphenols in chocolate [90].

Godočiková et al. [91] noticed that chocolate produced with the traditional method (with, among other, roasting stage) had almost twofold higher content of polyphenols compared to the "cold-processed" products.

Todorovic et al. [92] showed that for dark chocolate produced in Serbia, the total content of phenolics acid changed from $7.21 \pm 0.49$ to $12.65 \pm 0.45 \mathrm{mg} \mathrm{GAE} \mathrm{g}^{-1}$ in chocolate with $60-75 \%$ cocoa content.
The complexity of transformations to which polyphenols are subjected causes that the determined content of polyphenols may significantly differ between samples subjected to the same thermal processing. This is the result of the reaction to these compounds. According to numerous scientific studies, high temperature causes degradation of polyphenols and their content decreases significantly [21, 25]. However, as a result of the reaction to the polyphenols, different results can be obtained. One of the types of polyphenols present in cocoa beans and their processing products is tannins. Compounds are distinguished by chemical reactivity and biological activity. They can be hydrolysing and non-hydrolysing. Hydrolysing tannins are hydrolysed, among others, by acids that are formed during the fermentation process of beans. Similarly, they decompose to monomers under the influence of enzymes. However, procyanidins (nonhydrolyzing tannins) are oligomers or polymers of flavan-3-ols, $(-)$-epicatechins and (+)-catechins. High temperature may result not only in condensation of phenolic compounds to insoluble, complex tannins, but also in their decomposition to monomers.

Then, they are more easily available, and during the analysis you can mark their higher content. Moreover, tannins form permanent complexes with proteins, which makes it difficult to determine them.

Differences in the amount of determined polyphenolic compounds may also result from reactions with other components. Both monomers and polymers of phenolic compounds are partially bound or bound to polysaccharides, resulting in enzymatic reactions and the formation of bound and insoluble polyphenols, which are very difficult to determine. Depending on the composition of polyphenolic compounds and the degree of binding, a different number of complexes may be formed, and thus a different number of polyphenols may be determined.

Similar results can be obtained when proteins are present in the product. As a result of interaction between polyphenols and proteins (present in cocoa beans and chocolates), the bioavailability of proteins decreases and the determination of the total polyphenols content is difficult.

To sum up, the determination of polyphenols in chocolates is a complex process, determined by their content in cocoa beans, the type of polyphenolic compounds, the processes and parameters used in the technological process, as well as the chemical and raw material composition. Therefore, as confirmed by the above-mentioned studies, the content of polyphenolic compounds in chocolates obtained from roasted or unroasted beans may not confirm the thesis that high temperature has only destructive effect on phenolic compounds [25]. 


\section{"Raw" chocolate}

Due to the difference, as well as some innovativeness, the authors decided to devote a separate chapter of "raw" chocolate. Paying attention to this product is to signal that it is possible to produce chocolate using lower temperatures. Also because the sensory tests carried out by the authors (not published) have shown that despite the different organoleptic sensations, the product intrigued the panelists and received higher notes from "traditional" products. Raw chocolates are known to a small group of consumers, which additionally contributed to the distinction of this type of products.

Trying to meet expectations of consumers who pay attention not only to the quality of purchased products but also, and even foremost, to their composition, nutritive value and content of bioactive compounds, a technology has been developed for the production of "raw chocolate". In its production process, the "raw" chocolate is not exposed to high temperatures, cocoa beans are not subjected to the roasting process, and chocolate conching temperature does not exceed $45^{\circ} \mathrm{C}$, which enables preserving its valuable traits.

The results of study Żyżelewicz et al. [93] give evidence that it is possible to increase the content of healthy bioactive compounds, such as polyphenols and enhance the oxygen radical antioxidant capacity of chocolates by increasing the cocoa liquor content obtained from unroasted beans.

Raw chocolate is a rich source of magnesium, whose content is significantly higher than in "traditional" chocolate. Another important property of raw chocolate is its antioxidative potential. The ORAC value (Oxygen Radical Absorbance Capacity—capability to absorb oxygen radicals) of raw chocolate reaches approximately 28,000 units, which is one of the highest values noted worldwide. For instance, blueberries being one of the moste significant sources of antioxidants contain ca. 2400 units, whereas wine (Cabernet Sauvignon) only 5000 units. Above-mentioned products are a developing branch of the confectionery industry with wide perspectives. The low-temperature technological treatment which allows preserving antioxidants and protect fatty acids, as well as no alkalization, no use of palm sugar, and use of components and ingredients originating exclusively from bio-farming enables manufacturing a product with beneficial and expected sensory and health properties.

\section{Conclusions}

The bioactive compounds content in chocolate depends not only on the chemical composition of cocoa beans, but also on multi-oriented and complicated transformations of various character occurring at each stage of beans pretreatment and the technological process.
Processes of fermentation, drying, roasting, and alkalization are one of the most significant stages of cocoa beans processing, as they add to the development of many beneficial traits of chocolate. These positive changes may, however, be accompanied by reactions which significantly decrease the amounts of polyphenolic compounds. These undesirable results may be minimized by the standardization of the agricultural practices at the beginning of the supply chain and by improvement of the production process at critical points of cocoa beans pre-treatment.

The antioxidative properties of products of cocoa beans processing are also modified during chocolate production, mainly in the conching process. Significantly also under appropriate storage conditions of cocoa and chocolate products, including both optimal temperature (to preserve polyphenols below $50{ }^{\circ} \mathrm{C}$, for quality reasons below $20{ }^{\circ} \mathrm{C}$ ), humidity (in a dry place-under $75 \%$ ) and time (according to the date specified by the producer).

Referring to many studies on the content of polyphenolic compounds, or even bioactive ones, and the influence of technological processes and applied parameters on their content, it can be stated that there is no single dominant factor (stage, parameter) whose modification would allow to preserve these compounds. The authors also draw attention to the fact that one of the main factors guiding producers at all stages of cocoa bean processing is the economic factor. The economic factors are also driven by consumers, who occasionally reach for premium chocolate or raw chocolate with a much higher price. The specification of raw materials, their selection and unification is connected with the increase in prices. The analysis of the impact of the expected quality of raw materials on the process flow from the technological point of view, the quality of the finished product, as well as the costs incurred, does not provide commensurate benefits. The change of applied methods on plantations, their mechanization for the majority of farmers is unacceptable. In addition, a significant number of communities earn their living from cocoa cultivation and plantation work. One of the methods for increasing the homogeneity of semi-finished products is to increase supervision and, above all, to increase the awareness of those involved in the cultivation and processing of beans. Research shows that the use of high temperatures in the processing of cocoa beans reduces the content of biocomponents, but improves the technological process and gives the finished products the expected sensory characteristics. Therefore, it is necessary to find a golden mean between the technological process (its course, repeatability and economic factors) and the characteristics of chocolate in terms of its sensory characteristics (meeting customer expectations) and the content of bioactive components, including polyphenols. Greater control over the repeatability of processes on plantations, lowering the roasting 
temperature to a value enabling optimization of the process flow and preservation of bioactive components, lowering the conching temperature, elimination of alkalization are among the proposals left for consideration by scientists and producers.

Additionally, the collected data allow establishing at which stages and which processes require further studies and analyses, to be most useful for chocolate manufacturers not only in terms of manufacturing mass produced products but also in developing an assortment of products having a beneficial effect on human/consumer health and well-being.

Funding This research did not receive any specific grant from funding agencies in the public, commercial, or not-for-profit sectors.

\section{Compliance with ethical standards}

Conflict of interest The authors have no conflicts of interest to declare.

Compliance with ethics requirements This study does not contain any experiment involving human or animal subject.

Open Access This article is distributed under the terms of the Creative Commons Attribution 4.0 International License (http://creativeco mmons.org/licenses/by/4.0/), which permits unrestricted use, distribution, and reproduction in any medium, provided you give appropriate credit to the original author(s) and the source, provide a link to the Creative Commons license, and indicate if changes were made.

\section{References}

1. Biesalski HK, Dragsted LO, Elmadfa I, Grossklaus R, Müller M, Schrenk D, Weber P (2015) Bioactive compounds: definition and assessment of activity. Nutrition 25(11-12):1202-1205. https:// doi.org/10.1016/j.nut.2009.04.023

2. Correia M, Neves-Petersen MT, Jeppesen PB, Gregersen S, Petersen SB (2012) UV-light exposure of insulin: pharmaceutical implications upon covalent insulin dityrosine dimerization and disulphide bond photolysis. PLoS ONE 7(12):e50733. https://doi. org/10.1371/journal.pone.0050733

3. D'Souza RN, Grimbs S, Behrends B, Bernaert H, Ullrich MS, Kuhnert N (2017) Origin-based polyphenolic fingerprinting of Theobroma cacao in unfermented and fermented beans. Food Res Int 99:550-559. https://doi.org/10.1016/j.foodres.2017.06.007

4. Liu J, Liu M, He C, Song H, Guo J, Wang Y, Su X (2015) A comparative study of aroma-active compounds between dark and milk chocolate: relationship to sensory perception. J Sci Food Agric 95(6):1362-1372. https://doi.org/10.1002/jsfa.6831

5. Torres-Moreno M, Torrescasana E, Salas-Salvadó J, Blanch C (2015) Nutritional composition and fatty acids profile in cocoa beans and chocolates with different geographical origin and processing conditions. Food Chem 166:125-132. https://doi. org/10.1016/j.foodchem.2014.05.141

6. Yuan S, Li X, Jin Y, Lu J (2017) Chocolate consumption and risk of coronary heart disease, stroke, and diabetes: a meta-analysis of prospective studies. Nutrients 9(7):688. https://doi.org/10.3390/ nu9070688
7. Sirerol JA, Rodríguez ML, Mena S, Asensi MA, Estrela JM, Ortega AL (2016) Role of natural stilbenes in the prevention of cancer. Oxid Med Cell Longev 10:10. https://doi. org/10.1155/2016/3128951 (Hindawi Limited)

8. Krähmer A, Engel A, Kadow D, Ali N, Umaharan P, Kroh LW, Schulz H (2015) Fast and neat-determination of biochemical quality parameters in cocoa using near infrared spectroscopy. Food Chem 181:152-159. https://doi.org/10.1016/j.foodc hem.2015.02.084

9. Wollgast J, Anklam E (2000) Polyphenols in chocolate: is there a contribution to human health? Food Res Int 33(6):449-459. https ://doi.org/10.1016/S0963-9969(00)00069-7

10. Bordiga M, Locatell M, Travaglia F, Coïsson JD, Mazza G, Arlorio $M$ (2015) Evaluation of the effect of processing on cocoa polyphenols: antiradical activity, anthocyanins and procyanidins profiling from raw beans to chocolate. Int J Food Sci Technol 50(3):840-848. https://doi.org/10.1111/ijfs.12760

11. Pedan V, Fischer N, Rohn S (2016) An online NP-HPLC-DPPH method for the determination of the antioxidant activity of condensed polyphenols in cocoa. Food Res Int 89:890-900. https:// doi.org/10.1016/j.foodres.2015.10.030

12. Blanco-Andujar C, Orteg D, Southern P, Pankhurst QA, Thanh NTK (2015) High performance multi-core iron oxide nanoparticles for magnetic hyperthermia: microwave synthesis, and the role of core-to-core interactions. Nanoscale 7(5):1768-1775. https:// doi.org/10.1039/c4nr06239f

13. Aprotosoaie AC, Vald LS, Anca M (2016) Flavor chemistry of cocoa and cocoa products-an overview. Compr Rev Food Sci Food Saf 15(1):73-91. https://doi.org/10.1111/1541-4337.12180

14. Kothe L, Zimmermann BF, Galensa R (2013) Temperature influences epimerization and composition of flavanol monomers, dimers and trimers during cocoa bean roasting. Food Chem 141(4):3656-3663. https://doi.org/10.1016/j.foodc hem.2013.06.049

15. Giacometti J, Jolić S M, Josić D (2014) Cocoa processing and impact on composition. In: Processing and impact on active components in food, Elsevier Inc., pp 605-612. https://doi. org/10.1016/B978-0-12-404699-3.00073-1

16. Franco R, Oñatibia-Astibia A, Martínez-Pinilla E (2009) Health benefits of methylxanthines in cacao and chocolate. Nutr MDPI AG 5(10):4159-4173. https://doi.org/10.3390/nu5104159

17. Afoakwa EO, Paterson A, Fowler M, Ryan A (2008) Flavor formation and character in cocoa and chocolate: a critical review. Crit Rev Food Sci Nutr 48(9):840-857. https://doi.org/10.1080/10408 390701719272

18. Andújar I, Recio MC, Giner RM, Ríos JL (2012) Cocoa polyphenols and their potential benefits for human health. Oxid Med Cell Longev 10:23. https://doi.org/10.1155/2012/906252 (article ID 906252)

19. EFSA (2012) Scientific Opinion on the substantiation of a health claim related to cocoa flavanols and maintenance of normal endothelium-dependent vasodilation pursuant to Article 13(5) of Regulation (EC) No 1924/2006. EFSA J 10(7):2809-2830. https ://doi.org/10.2903/j.efsa.2012.2809

20. Giacometti J, Muhvić D, Pavletić A, Dudarić L (2016) Cocoa polyphenols exhibit antioxidant, anti-inflammatory, anticancerogenic, and anti-necrotic activity in carbon tetrachloride-intoxicated mice. J Funct Foods 23:177-187. https://doi.org/10.1016/j. jff.2016.02.036

21. Ioannone F, Di Mattia CD, De Gregorio M, Sergi M, Serafini M, Sacchetti G (2015) Flavanols, proanthocyanidins and antioxidant activity changes during cocoa (Theobroma cacao L.) roasting as affected by temperature and time of processing. Food Chem 174:256-262. https://doi.org/10.1016/j.foodchem.2014.11.019

22. Martini S, Conte A, Tagliazucchi D (2018) Comprehensive evaluation of phenolic profile in dark chocolate and dark chocolate 
enriched with Sakura green tea leaves or turmeric powder. Food Res Int 11:1-16. https://doi.org/10.1016/j.foodres.2018.06.020

23. Gomez-Juaristi M, Gonzalez-Torres L, Bravo L, Vaquero MP, Bastida S, Sanchez-Muniz FJ (2011) Beneficial effects of chocolate on cardiovascular health. Nutr Hosp 26(2):289-292. https:// doi.org/10.1590/S0212-16112011000200007

24. Martorell P, Forment JV, De Llanos R, Montón F, Llopis S, González N, Ramón D (2011) Use of Saccharomyces cerevisiae and Caenorhabditis elegans as model organisms to study the effect of cocoa polyphenols in the resistance to oxidative stress. J Agric Food Chem 59(5):2077-2085. https://doi.org/10.1021/jf104 $217 \mathrm{~g}$

25. Di Mattia CD, Sacchetti G, Mastrocola D, Serafini M (2017) From cocoa to chocolate: the impact of processing on in vitro antioxidant activity and the effects of chocolate on antioxidant markers in vivo. Front Immunol 8:1207. https://doi.org/10.3389/fimmu .2017 .01207

26. Cinquanta L, Di Cesare C, Manoni R, Piano A, Roberti P, Salvatori $\mathrm{G}$ (2016) Mineral essential elements for nutrition in different chocolate products. Int J Food Sci Nutr 67(7):773-778. https:// doi.org/10.1080/09637486.2016.1199664

27. Kerimi A, Williamson G (2015) The cardiovascular benefits of dark chocolate. Vasc Pharmacol 71:11-15. https://doi. org/10.1016/j.vph.2015.05.011

28. Patel K, Watson RR (2018) Chocolate and its component's effect on cardiovascular disease. Lifestyle Heart Health Dis. https://doi. org/10.1016/b978-0-12-811279-3.00021-5

29. Seem SA, Yuan YV, Tou JC (2019) Chocolate and chocolate constituents influence bone health and osteoporosis risk. Nutrition 10:10. https://doi.org/10.1016/j.nut.2019.02.011

30. Torres-Moreno M, Tarrega A, Costell E, Blanch C (2012) Dark chocolate acceptability: influence of cocoa origin and processing conditions. J Sci Food Agric 92(2):404-411. https://doi. org/10.1002/jsfa.4592

31. Machálková L, Hřivna L, Nedomová Š, Jůzl M (2015) The effect of storage temperature on the quality and formation of blooming defects in chocolate confectionery. Potravinarstvo 9(1):39-47. https://doi.org/10.5219/425

32. Serafini M, Bugianesi R, Maiani G, Valtuena S, De Santis S, Crozier A (2003) Plasma antioxidants from chocolate. Nature 424(6952):1013. https://doi.org/10.1038/4241013a

33. Araujo R, Fernandes C, Ribeiro D, Efraim P, Steinmacher D, Lieberei R, Bastide P, Araujo T (2014) Cocoa Quality Index A proposal. Food Control 46:49-54

34. Nehlig A (2013) The neuroprotective effects of cocoa flavanol and its influence on cognitive performance. Br J Clin Pharmacol 75(3):716-727. https://doi.org/10.1111/j.1365-2125.2012.04378 .X

35. McShea A, Ramiro-Puig E, Munro SB, Casadesus G, Castell M, Smith MA (2008) Clinical benefit and preservation of flavonols in dark chocolate manufacturing. Nutr Rev 66:630-641. https:// doi.org/10.1111/j.1753-4887.2008.00114.x

36. Beckett ST (2008) Traditional chocolate making. In: Beckett ST (ed) Industrial chocolate manufacture and use, 4th edn. WileyBlackwell Science, New York

37. Amoye S (2006) Cocoa sourcing, world economics and supply. Manuf Confect 86(1):81-85

38. Motamayor JC, Lachenaud P, da Silva e Mota JW, Loor R, Kuhn DN, Brown JS, Schnell RJ (2008) Geographic and genetic population differentiation of the Amazonian chocolate tree (Theobroma cacao L.). PLoS One 3(10):10. https://doi.org/10.1371/journ al.pone.0003311

39. Afoakwa EO, Quao J, Budu AS, Takrama J, Saalia FK (2011) Effect of pulp preconditioning on acidification, proteolysis, sugars and free fatty acids concentration during fermentation of cocoa
(Theobroma cacao) beans. Int J Food Sci Nutr 62(7):755-764. https://doi.org/10.3109/09637486.2011.581224

40. Saltini R, Akkerman R, Frosc S (2013) Optimizing chocolate production through traceability: a review of the influence of farming practices on cocoa bean quality. Food Control 29(1):167-187. https://doi.org/10.1016/j.foodcont.2012.05.054

41. Trognitz B, Cros E, Assemat S, Davrieux F, Forestier-Chiron N, Ayestas E et al (2013) Diversity of cacao trees in Waslala, Nicaragua: associations between genotype spectra, product quality and yield potential. PLoS One. https://doi.org/10.1371/journ al.pone.0054079

42. Jahurul MHA, Zaidul ISM, Norulaini NAN, Sahena F, Jinap S, Azmir J et al (2013) Cocoa butter fats and possibilities of substitution in food products concerning cocoa varieties, alternative sources, extraction methods, composition, and characteristics. J Food Eng 117:467-476. https://doi.org/10.1016/j.jfood eng.2012.09.024 (Elsevier Ltd.)

43. Ortiz de Bertorelli L, Graziani De Farinas L, Rovedas LG (2009) Influencia de varios factores sobre características del grano de cacao fermentado y secado al sol. Agronomía Tropical 59(2):119-127

44. Ho VTT, Zhao J, Fleet G (2014) Yeasts are essential for cocoa bean fermentation. Int J Food Microbiol 174:72-87. https://doi. org/10.1016/j.ijfoodmicro.2013.12.014

45. Peláez P, Bardón I, Camasca P (2016) Methylxanthine and catechin content of fresh and fermented cocoa beans, dried cocoa beans, and cocoa liquor. Scientia Agropecuaria 7:355-365. https ://doi.org/10.17268/sci.agropecu.2016.04.01

46. Oracz J, Zyzelewicz D, Nebesny E (2015) The content of polyphenolic compounds in cocoa beans (Theobroma cacao L.), depending on variety, growing region, and processing operations: a review. Crit Rev Food Sci Nutr 55(9):1176-1192. https://doi. org/10.1080/10408398.2012.686934

47. Bortolini C, Patrone V, Puglisi E, Morelli L (2016) Detailed analyses of the bacterial populations in processed cocoa beans of different geographic origin, subject to varied fermentation conditions. Int J Food Microbiol 236:98-106. https://doi.org/10.1016/j.ijfoo dmicro.2016.07.004

48. Bruna C, Eichholz I, Rohn S, Kroh LW, Huyskens-Keil S (2009) Bioactive compounds and antioxidant activity of cocoa hulls (Theobroma cacao L.) from different origins. J Appl Botany Food Qual-Angewandte Botanik 83(1):9-13

49. Macedo ASL, de Souza Rocha F, da Silva Ribeiro M, Soares SE, da Silva Bispo E (2016) Characterization of polyphenol oxidase in two cocoa (Theobroma cacao L.) cultivars produced in the south of Bahia. Brazil. Food Sci Technol 36(1):56-63. https://doi. org/10.1590/1678-457X.0009

50. Carrillo LC, Londoño-Londoño J, Gil A (2014) Comparison of polyphenol, methylxanthines and antioxidant activity in Theobroma cacao beans from different cocoa-growing areas in Colombia. Food Res Int 60:273-280. https://doi.org/10.1016/j. foodres.2013.06.019

51. Leal GA, Gomes LH, Efraim P, De Almeida Tavares FC, Figueira A (2008) Fermentation of cacao (Theobroma cacao L) seeds with a hybrid Kluyveromyces marxianus strain improved product quality attributes. FEMS Yeast Res 8(5):788-798. https://doi.org/10.1 111/j.1567-1364.2008.00405.x

52. Lefeber T, Papalexandratou Z, Gobert W, Camu N, De Vuyst L (2012) On-farm implementation of a starter culture for improved cocoa bean fermentation and its influence on the flavour of chocolates produced thereof. Food Microbiol 30(2):379-392. https:// doi.org/10.1016/j.fm.2011.12.021

53. Crafack M, Mikkelsen MB, Saerens S, Knudsen M, Blennow A, Lowor S, Takrama J, Swiegers JH, Petersen GB, Heimdal H, Nielsen DS (2013) Influencing cocoa flavour using Pichia kluyveri 
and Kluyveromyces marxianus in a defined mixed starter culture for cocoa fermentation. Int J Food Microbiol 167(1):103-116. https://doi.org/10.1016/j.ijfoodmicro.2013.06.024

54. Cruz JFM, Leite PB, Soares SE, Bispo ES (2013) Assessment of the fermentative process from different cocoa cultivars produced in Southern Bahia, Brazil. Afr J Biotechnol 12(33):5218-5225. https://doi.org/10.5897/AJB2013.12122

55. Efraim P, Alves AB, Jardim DCP (2011) Polifenóis em cacau e derivados: teores, fatores de variação e efeitos na saúde. Braz J Food Technol 14(3):181-201. https://doi.org/10.4260/BJFT2 011140300023

56. Afoakwa EO, Quao J, Takrama J, Budu AS, Saalia FK (2013) Chemical composition and physical quality characteristics of Ghanaian cocoa beans as affected by pulp pre-conditioning and fermentation. J Food Sci Technol 50(6):1097-1105. https://doi. org/10.1007/s13197-011-0446-5

57. Elwers S, Zambrano A, Rohsius C, Lieberei R (2009) Differences between the content of phenolic compounds in Criollo, Forastero and Trinitario cocoa seed (Theobroma cacao L.). Eur Food Res Technol 229(6):937-948. https://doi.org/10.1007/s0021 7-009-1132-y

58. Afoakwa EO, Kongor JE, Takrama J, Budu AS (2013) Changes in nib acidification and biochemical composition during fermentation of pulp pre-conditioned cocoa (Theobroma cacao) beans. Int Food Res J 20(4): 1843-1853

59. Koua BK, Koffi PM, Gbahab P (2017) Evolution of shrinkage, real density, porosity, heat and mass transfer coefficients during indirect solar drying of cocoa beans. J Saudi Soc Agric Sci 7:1-11. https://doi.org/10.1016/j.jssas.2017.01.002

60. Bonaparte A, Alikhani Z, Madramootoo CA, Raghavan V (1998) Some quality characteristics of solar-dried cocoa beans in St Lucia. J Sci Food Agric 76(4):553-558. https://doi. org/10.1002/(SICI)1097-0010(199804)76:4\%3c553:AID-JSFA9 $86 \% 3 \mathrm{e} 3.0 . \mathrm{CO} ; 2-\mathrm{V}$

61. Zahouli GIB, Guehi ST, Fae AM, Nemlin JG (2010) Effect of drying methods on the chemical quality traits of cocoa raw material. Adv J Food Sci Technol 2(4):184-190

62. Bernaert N, De Paepe D, Bouten C, Declercq H, Stewart D, Van Bockstaele E, Van Droogenbroeck B (2012) Antioxidant capacity, total phenolic and ascorbate content as a function of the genetic diversity of leek (Allium ampeloprasum var. porrum). Food Chem 134(2):669-677. https://doi.org/10.1016/j.foodchem.2012.02.159

63. García-Alamilla P, Salgado-Cervantes MA, Barel M, Berthomieu G, Rodríguez-Jimenes GC, García-Alvarado MA (2007) Moisture, acidity and temperature evolution during cacao drying. J Food Eng 79(4):1159-1165. https://doi.org/10.1016/j.jfood eng.2006.04.005

64. Hii CL, Rahman RA, Jinap S, Man YBC (2006) Quality of cocoa beans dried using a direct solar dryer at different loadings. J Sci Food Agric 86(8):1237-1243. https://doi.org/10.1002/jsfa.2475

65. Bharath S, Bowen-O'Connor C (2008) Assessing drying rates of cacao beans using small samples. St. Augustine, Trinidad: Cocoa Research Unit, U.W.I. Annual report (pp 52-58)

66. Chinenye NM (2009) Effect of drying temperature and drying air velocity on the drying rate and drying constant of cocoa bean. Manuscript, XI http://cigrjournal.org/index.php/Ejounral/article/ viewFile/1091/1172. Accessed Jan 2018

67. de Brito ES, Garcia NH, Gallao MI, Cortelazzo AL, Fevereiro PS, Braga MR (2001) Structural and chemical changes in cocoa (Theobroma cacao L.) during fermentation, drying and roasting. J Sci Food Agric 81:281-288. https://doi.org/10.1002/10970010(20010115)81:2\%3c281:Aid-Jsfa808\%3e3.0.Co;2-B

68. de Muijnck L (2005) Cocoa. Encapsulated and powdered foods. CRC Press, London, pp 451-473
69. Kongor JE, Hinneh M, de Walle DV, Afoakwa EO, Boeckx P, Dewettinck K (2016) Factors influencing quality variation in cocoa (Theobroma cacao) bean flavour profile-a review. Food Res Int 82:44-52. https://doi.org/10.1016/j.foodres.2016.01.012

70. del Brunetto MR, Gutiérrez L, Gallignani M, Zambrano A, Gómez $\tilde{A}$, Romero C (2007) Determination of theobromine, theophylline and caffeine in cocoa samples by a high-performance liquid chromatographic method with on-line sample cleanup in a switching-column system. Food Chem 100:459-467. https://doi. org/10.1016/j.foodchem.2005

71. Camu N, De Winter T, Addo SK, Takrama JS, Bernaert H, De Vuyst L (2008) Fermentation of cocoa beans: influence of microbial activities and polyphenol concentrations on the flavour of chocolate. J Sci Food Agric 88(13):2288-2297. https://doi. org/10.1002/jsfa.3349

72. Farah DMH, Zaibunnisa AH, Misnawi J, Zainal S (2012) Effect of roasting process on the concentration of acrylamide and pyrazines in roasted cocoa beans from different origins. APCBEE Proc 4:204-208. https://doi.org/10.1016/j.apcbee.2012.11.034

73. Hurst WJ, Krake SH, Bergmeier SC, Payne MJ, Miller KB, Stuart DA (2011) Impact of fermentation, drying, roasting and Dutch processing on flavan-3-ol stereochemistry in cacao beans and cocoa ingredients. Chem Central J 5(53):10. https://doi. org/10.1186/1752-153X-5-53

74. Stanley TH, Van Buiten B, Baker SA, Elias RJ, Anantheswaran RC, Lambert JD (2018) Impact of roasting on the flavan-3-ol composition, sensory-related chemistry, and in vitro pancreatic lipase inhibitory activity of cocoa beans. Food Chem 255:414-420. https ://doi.org/10.1016/j.foodchem.2018.02.036

75. Oracz J, Nebesny E (2016) Antioxidant properties of cocoa beans (Theobroma cacao L.): influence of cultivar and roasting conditions. Int J Food Prop 19(6):1242-1258. https://doi. org/10.1080/10942912.2015.1071840

76. Żyżelewicz D, Krysiak W, Nebesny E, Budryn G (2014) Application of various methods for determination of the color of cocoa beans roasted under variable process parameters. Eur Food Res Technol 238(4):549-563. https://doi.org/10.1007/s0021 7-013-2123-6

77. Gültekin-Özgüven M, Berktaş I, Özçelik B (2016) Influence of processing conditions on procyanidin profiles and antioxidant capacity of chocolates: optimization of dark chocolate manufacturing by response surface methodology. LWT Food Sci Technol 66:252-259. https://doi.org/10.1016/j.1wt.2015.10.047

78. Żyżelewicz D, Oracz J, Sosnowska D, Nebesny E (2016) The influence of the roasting process conditions on the polyphenol content in cocoa beans, nibs and chocolates. Food Res Int 89:918-929

79. Andres-Lacueva C, Khan N, Izquterdo-Pulido M, Urpi-Sarda M, Permanyer J, Lamuela-Raventós RM (2008) Flavanol and flavonol contents of cocoa powder products: influence of the manufacturing process. J Agric Food Chem 56(9):3111-3117. https://doi. org/10.1021/jf0728754

80. Noor-Soffalina SS, Jinap S, Nazamid S, Nazimah SAH (2009) Effect of polyphenol and $\mathrm{pH}$ on cocoa Maillard-related flavour precursors in a lipidic model system. Int J Food Sci Technol 44(1):168-180. https://doi.org/10.1111/j.1365-2621.2008.01711.x

81. Miller KB, Stuart DA, Smith NL, Lee CY, Mchale NL, Flanagan JA, Hurst WJ (2006) Antioxidant activity and polyphenol and procyanidin contents of selected commercially available cocoacontaining and chocolate products in the United States. J Agric Food Chem 54(11):4062-4068. https://doi.org/10.1021/jf060290o

82. Jolić SM, Redovnikovic IR, Markovic K, Sipusic DI, Delonga K (2011) Changes of phenolic compounds and antioxidant capacity in cocoa beans processing. Int J Food Sci Technol 46:1793-1800. https://doi.org/10.1111/j.1365-2621.2011.02670.x 
83. Li Y, Feng Y, Zhu S, Luo C, Ma J, Zhong F (2012) The effect of alkalization on the bioactive and flavor related components in commercial cocoa powder. J Food Compos Anal 25(1):17-23. https://doi.org/10.1016/j.jfca.2011.04.010

84. Stanley TH, Smithson AT, Neilson AP, Anantheswaran RC, Lambert JD (2015) Analysis of cocoa proanthocyanidins using reversed phase high-performance liquid chromatography and electrochemical detection: application to studies on the effect of alkaline processing. J Agric Food Chem 63:5970-5975. https:// doi.org/10.1021/acs.jafc.5b02661

85. Bolenz S, Thiessenhusen T, Schäpe R (2003) Fast conching for milk chocolate. Eur Food Res Technol 218(1):62-67. https://doi. org/10.1007/s00217-003-0790-4

86. Kruszewski B, Obiedziński MW, Kowalska J (2018) Nickel, cadmium and lead levels in raw cocoa and processed chocolate mass materials from three different manufacturers. J Food Compos Anal 66:127-135. https://doi.org/10.1016/j.jfca.2017.12.012

87. Gutiérrez TJ (2017) State-of-the-art chocolate manufacture: a review. Compr Rev Food Sci Food Saf. 10:10. https://doi. org/10.1111/1541-4337.12301 (Blackwell Publishing Inc.)

88. Wollgast J, Anklam E (2000) Review on polyphenols in Theobroma cacao: changes in composition during the manufacture of chocolate and methodology for identification and quantification. Food Res Int 33(6):423-447. https://doi.org/10.1016/S0963 -9969(00)00068-5

89. Crichton GE, Elias MF, Alkerwi A (2016) Chocolate intake is associated with better cognitive function: the
Maine-syracuse longitudinal study. Appetite 100:126-132. https ://doi.org/10.1016/j.appet.2016.02.010

90. Jalil AMM, Ismail A (2008) Polyphenols in cocoa and cocoa products: is there a link between antioxidant properties and health? Molecules 13(9):2190-2219. https://doi.org/10.3390/molecules1 3092190

91. Godočiková L, Ivanišová E, Árvay J, Petrová J, Kačániová M (2016) The comparison of biological activity of chocolates made by different technological procedures. Potravinarstvo 10(1):316322. https://doi.org/10.5219/628

92. Todorovic V, Vidovic B, Todorovic Z, Sobajic S (2017) Correlation between antimicrobial, antioxidant activity, and polyphenols of alkalized/nonalkalized cocoa powders. J Food Sci 82(4):1020 1027. https://doi.org/10.1111/1750-3841.13672

93. Żyżelewicz D, Budryn G, Oracz J, Antolak H, Kręgiel D, Kaczmarska M (2018) The effect on bioactive components and characteristics of chocolate by functionalization with raw cocoa beans. Food Res Int 113:234-244. https://doi.org/10.1016/j.foodr es.2018.07.017

Publisher's Note Springer Nature remains neutral with regard to jurisdictional claims in published maps and institutional affiliations. 